\title{
MARITIME EXPANSION AND DELIMITATION AFTER THE TIMOR GAP TREATY
}

\author{
Marcel Hendrapati*
}

\begin{abstract}
* Lecturer of International Law, Faculty of Law, Hasanuddin University. Obtained Bachelor of Law (S.H.) from Hasanuddin University (1979), Master of Law (M.H.) from Padjadjaran University (1993), and Doctor of Philosophy (Dr) from Hasanuddin University (2013).
\end{abstract}

\author{
Article Info \\ Received : 5 February 2015 | Received in revised form : 9 March 2015 | Accepted : 9 April 2015 \\ Corresponding author's e-mail : mhendrapati@yahoo.com
}

\begin{abstract}
The Timor Gap Treaty on oil and gas management cooperation in some parts of the Timor Sea was full of political intrigues between Australia and Republic of Indonesia, since the treaty which comprises three areas of cooperation was detrimental to Indonesia and it indicated the highest influence of Indonesian Republic by Australia. Renunciation of the treaty due to the independence of Timor Leste after a referendum resulted in the issue of maritime delimitation between Timor Leste and Indonesia. Nevertheless in fact in 2002 the new state declared maritime expansion to a distance of 100 nautical miles measured from the former Timor Gap lines. The result of the expansion was that it potentially reached to Indonesian oil and gas fields located in the west and east of the lines. Apparently the unilateral expansion conducted by the country which from 1975 until 1999 was the $27^{\text {th }}$ province of Indonesian Republic motivated both states to accelerate maritime delimitation aimed at achieving equitable solution. to it, such as the maritime expansion and implementation of the equitable solution principle in maritime delimitation between the two states after the Timor Gap Treaty.
\end{abstract}

Keywords: delimitation, equidistance, equitable solution, maritime expansion, timor gap, timor sea.

\begin{abstract}
Abstrak
Perjanjian Celah Timor mengenai kerjasama pengelolaan migas di Laut Timor sarat dengan intrik politik antara Australia dan Indonesia, karena ternyata perjanjian yang mencakup tiga zona kerjasama merugikan Indonesia serta menunjukkan kuatnya pengaruh Australia terhadap Indonesia pada masa itu.Pembatalan perjanjian tersebut akibat kemerdekaan Timor Leste setelah referendum menimbulkan isu delimitasi maritim antaraIndonesia dan Timor Leste. Namun ternyata pada tahun 2002Timor Leste memperluas secara sepihak zona maritimnya sejauh 100 mil laut dengan menggunakan garis-garis bekas Celah Timor sehingga dikawatirkan berpotensi mencapai ladang migas Indonesia yang berada di sebelah barat dan timur dari garis-garis tersebut. Tampaknya ekspansi sepihak negara yang dari tahun 1975 hingga 1999 merupakan provinsi Republik Indonesia ke27 ini mendorong kedua negara untuk mempercepat dilakukannya berbagai negosiasi delimitasi maritim, khususnya delimitasi zona ekonomi eksklusif di kawasan tersebut. Artikel ini mengkaji substansi perjanjian Celah Timor dan perluasan maritim negara tetangga dan penerapan prinsip solusi yang berkeadilan dalam menetapkan garis batas maritim keduanegara setelah perjanjian Celah Timor.
\end{abstract}

Katakunci: celah timor, delimitasi, ekspansi maritim, laut timor, sama jarak, solusi berkeadilan. 


\section{Introduction}

The Timor Gap Treaty between Indonesia and Australia is assumed by many people to be a treaty of continental shelf boundaries in Timor Sea. This perception is not exactly correct since the two states had previously concluded an agreement concerning boundaries of the continental shelf in Arafura Sea and in the Northern Area of Irian Jaya in 1971. It was followed by another agreement regarding the establishment of continental shelf boundaries in the South of Tanimbar Island and Timor Island. This agreement was signed in $1973 .^{1}$

The Timor Gap Treaty is not a treaty concerning boundaries of continental shelf, but a provisional agreement regulating management cooperation for oil and gas existing in parts of the seabed and subsoil in Timor Sea. The management cooperation arrangement concluded by the two states is a provisional one because it does not contain an agreement regarding boundary lines of the continental shelf overlapping parts of the Timor Sea in 1971. This provisional agreement on the cooperation for oil and gas management in the Timor Gap was to avoid the occurrence of conflict between the two states as a result of the issue of oil and gas exploration.

On $25^{\text {th }}$ October, 1989, Indonesia and Australia successfully concluded the agreement on management cooperation for oil and gas located in some parts of the seabed in the Timor Sea, hereafter called Timor Gap. As long as the two states have not reached any agreement with respect to the establishment of the continental shelf's boundaries in the Timor Gap, in accordance to valid law provisions, the joint management agreement of 1989, whose status was provisional, should prevail. Indonesia and Australia ratified the concerned treaty and so they have to respect and implement the provisions of the treaty based on the principle of pacta sunt sevanda.

After East Timor which was the $27^{\text {th }}$ Indonesian province obtained freedom and sovereignty from Indonesia in compliance with the referendum results, the agreement was automatically terminated, since the object stipulated in that agreement, that is the area called the Timor Gap located in a certain part of the Timor Sea is no longer an interest of Indonesia, but the interest of Timor Leste and Australia. ${ }^{2}$ Certainly, the separation of East Timor from Indonesia resulted in the loss of much foreign exchange from oil and gas exploration and exploitation in the continental shelf of parts of Timor Sea. Indonesia was forced to accept this because the President B.J.Habibie, in 1998 proposed two options without any approval of Indonesian parliament. One of the option was that if East Timor's society still wanted to be part of the Indonesian people, East Timor would be given a special status, namely as a special autonomous region within the Indonesian state. The second option was that if its society no longer wants to be part of Indonesia, then Indonesia's government would let Timor Leste express its right to self-determination. A referendum would have to be conducted by the United Nations through a special agency which was called 'United Nations Mission for East Timor' (UNAMET). The referendum result showed that a greater part of the population of East Timor chose to separate from the Indonesian State. Whether the referendum was free and fair is another issue entirely.

As a consequence of East Timor's separation, the Timor Gap Treaty which had

\footnotetext{
${ }^{1}$ Mochtar Kusumaatmadja, Hukum Laut International Law (Bandung: Penerbit Binacipta, 1978), p.201. See also Hasjim Djalal, Perjuangan Indonesia di Bidang Hukum Laut (Jakarta: Badan Penelitian dan Pengembangan, Departemen Luar Negeri Republik Indonesia, 1986), p.22.

${ }^{2}$ Huala Adolf, "Beberapa Masalah Suksesi Negara Dalam Kasus Timor Timur," http://resources. unpad-content/uploads/publication, accessed 1 November 2013.
} 
been in place for about ten years automatically terminated with the Indonesia's loss of interest in the continental shelf area located in the Timor Gap. Nevertheless, the renunciation of the treaty needed a separate agreement, for it to have a legal backing, between the two states or even among the three states, i.e. Indonesia, Australia and Timor Leste for the sake of avoiding any possible conflict in the future. The Timor Gap treaty was abrogated by an agreement between the two governments of Indonesia and Australia through exchange of correspondence.

The legal backing of the treaty abrogation and efforts to avoid any possible dispute are important in preserving good relations among Indonesia, Australia and Timor Leste. The achievement of the rule of law could contribute to and maintain peace and security in the Pacific Region and so there should be a formal agreement abrogating the Timor Gap Treaty signed in 1989. Various groups in Indonesia expressed dissatisfaction with the treaty and regarded it as very harmful to Indonesia. ${ }^{3}$

On 10 February 2000 Australia and the UNTAET (United Nations Transitional Administration in East Timor) reached an agreement on the continued operation of the Timor Gap Treaty, since all rights and obligations under the treaty previously exercised by Indonesia are assumed by the UNTAET, acting on behalf of East Timor, and Australia may enter into subsidiary arrangements relating to the continued operation of the terms of the treaty. ${ }^{4}$ On 5 July 2001 the UNTAET and Australia adopted a Memorandum of Understanding replacing the 2000 agreement. The 2001 Memorandum of Understanding established the Joint Petroleum Development Area (JPDA), which covers precisely the same area as stipulated in the 1989 Timor Gap Treaty. ${ }^{5}$

Republic of Indonesia had already concluded 16 maritime boundary agreements covering a variety of zones such as the boundaries of territorial sea, the boundaries of continental shelf and the boundaries of exclusive economic zone with 8 neighbouring states. ${ }^{6}$ Indonesia does not yet have maritime boundaries with Timor Leste, since the two countries have not been successful in agreeing some land boundary points (two points in Oecussi district and one point in Timor). Nevertheless both states reached an agreement on maritime boundary delimitation, disregarding the unilateral expansion conducted by the neighbouring country.

This paper argues that negotiation is imperative on maritime boundaries regarding the exclusive economic zone in the Timor Sea involves Republic of Indonesia, Timor Leste and Australia, since the coastal areas of each state are directly adjacent to the Timor Sea. In addition, delimitation of the exclusive economic zone should be urgently conducted in order to not only ensure a legal certainty with respect to the sovereign rights and jurisdiction of each state, but also to eradicate any potential conflict which

3 Yoshifumi Tanaka (1), Predictability and Flexibility in the Law of Maritime Delimitation (Oxford: Hart Publishing, 2006), pp.284 - 285. See also "Pembagian Tambang Minyak di Celah Timor Merugikan," Kompas (1989): 1.

${ }^{4}$ Adolf, loc.cit. The Agreement between Australia and Indonesia regarding Timor Gap Zone of Cooperation was terminated by the two governments after referendum with the result that the continued operation of Timor Gap Treaty was implemented based on Memorandum of Understanding adopted by Australia and UNTAET concerning the new joint development arrangement. In this case UNTAET played the role as transitional administration in East Timor..

${ }^{5}$ Ibid.

${ }^{6}$ Arif Havas Oegroseno, "Status Hukum Pulau-Pulau Terluar Indonesia," Indonesian Journal of International Law Vol. 6 No. 3 (April 2009): 312 - 313. Besides some points being located in border areas, the existence of Wetar island owned by Indonesia in the Timor Sea has to be considered as a relevant circumstance, in this case as a geographical factor during negotiations between Indonesia and Timor Leste. 
may occur in those waters with the result that the various cases regarding territorial and jurisdictional limit violation, mainly the accusation of illegal fishing by the other states against the Indonesian traditional fishermen will not occur anymore. Without maritime boundary agreement, it is difficult for Indonesian government to protect its citizens especially for traditional Indonesian fishermen for jurisdictional violations. As long as the state concerned maintains its consistent attitude in the field of law enforcement towards any violation of territorial limit and such territorial and jurisdictional limit is determined by a unilateral act, Indonesia faces a tough situation regarding the condition of its traditional fishermen in the Timor Sea.

This article outlines as follows to explain: 1) the substance of Timor Gap Treaty which was signed by Indonesia and Australia in 1989; 2) the recent development relating to unilateral maritime expansion conducted by the government of Timor Leste, establishing its exclusive economic zone measured from the eastern and western lines of the former Timor Gap with the result that the unilateral expansion would disturb Indonesian sovereignty in certain parts of Timor Sea; 3) maritime delimitation between Indonesia and Timor Leste.

\section{The Timor Gap Treaty 1989}

In 1972 Indonesia and Australia reached an agreement on the continental shelf boundary lines in a part of Timor Sea, that is, the part of Timor Sea adjacent to the Indonesian territory in Nusa Tenggara Timur and Australian Northern Territory. In the same year, another agreement was reached between the two states regarding continental shelf boundaries in a part of Arafura Sea. ${ }^{7}$ This continental shelf is located in another part of Timor Sea, i.e. the part of Timor Sea between Indonesian territory in East Timor and Australian Northern Territory. As a part of Timor Sea, the continental shelf concerned seems to be sandwiched. Because there was no concrete agreement yet, a disagreement ensued between the two states, i.e. how far could the jurisdiction of each state extend on the continental shelf between Indonesian territory in East Timor and the "Northern Territory" of Australia? The uncertain condition relating to continental shelf boundaries due to overlapping claims had been going on since 1972 . Such the condition was resulted in disagreement regarding delimitation of continental shelf between Indonesian territory in East Timor and Northern Territory of Australia. Nevertheless in 1989 Indonesia and Australia reached to a joint development arrangement in the Timor Gap as overlapping zone in the Timor Sea. This zone is known to contain deposits of petroleum and natural gas. ${ }^{8}$

\section{A. Contradictory Opinion}

The overlapping claims to continental shelf boundaries in parts of Timor Sea between the two states emerged because there are different perceptions and approaches in stipulating sovereign rights and jurisdiction on the continental shelf called Timor Gap. Australia applies geological or geomorphologic approach and technical exploitability criteria in stipulating the jurisdiction limits over the seabed and subsoil ${ }^{9}$ since Australia relies on the natural prolongation claim found in article

\footnotetext{
${ }^{7}$ Hasjim Djalal, "Mengelola Potensi Laut Indonesia," (presented at Pelatihan Diplomasi dan Hubungan Internasional Bagi Pejabat Pemerintah Daerah Sulawesi Selatan, Makassar, December 2003).

${ }^{8}$ Victor Prescott and Clive Schofield, The Maritime Political Boundaries of the World (Leiden: Martinus Nijhoff Publishers, 2005), pp.462 - 463. See also Frans Sarong, "Celah Timor, Daerah Tumpang Tindih," Teropong Kompas (2001): 25.

${ }^{9}$ Ibid.
} 
76 (1) of the 1982 Convention and Australia ratified the 1958 Geneva Convention on continental shelf which was valid when the two states started discussing the continental shelf boundary lines in 1969. Australia however did not want to implement a principle rule in article 6 of the convention which stipulated inter alia:

"Where the same continental shelf is adjacent to the territories of two or more states whose coasts are opposite each other, the boundary of the continental shelf pertaining to such states shall be determined by an agreement between them. In the absence of an agreement, and unless another boundary line is justified by special circumstances, the boundary is the median line; every point of the baselines from the breadth of the territorial sea of each state is measured".

By making use of geological and geomorphologic approach, Australia claimed limit of its continental shelf to the limit called "bathymetric axis" at Timor Trench in the southern coast of East Timor. This perception has consistently been maintained since 1972 and even before then when the two states met to discuss the issue of continental shelf boundaries of East Timor and the northern coast of Australia. It is known that far before 1972, Australia commenced exploration activities in the area concerned through its mining company, since far before Timor Leste joined with Indonesia, Portugal as the ruler of East Timor had never agreed the maritime limits between the East Timor's territory and Australia. ${ }^{10}$

Concerning the perception of Indonesia to the delimitation of continental shelf boundaries in the Timor Gap, it is necessary to underline that at that time, the Republic of Indonesia didn't consent to be bound by the 1958 Geneva Convention on Continental Shelf, since the Secretary General of United Nations merely accepted the ratification of the Geneva Convention on the High Seas, while the ratification of the Geneva Convention on the Territorial Sea and Contiguous Zone was not accepted by the UN Secretary General. ${ }^{11}$ Nevertheless, Indonesia does consistently implement the main provisions and principles of Geneva Convention on the Continental Shelf, according to Law number 1, year 1973 regarding the continental shelf of Indonesia, which did refer to the Geneva Convention on the Continental Shelf.

Article 3 of the law number 1 year 1973 stipulates that ${ }^{12}$

"in case Indonesian continental shelf, including depressions existing in it, is adjacent to other states, the continental shelf delimitation with other states may be conducted through negotiation aimed at achieving any agreement." that: ${ }^{13}$

Promulgation of the Government of the Republic of Indonesia declares inter alia

"In cases where the Indonesian continental shelf, including the depressions on the continental shelf or Indonesian archipelago, borders another State the Government of the Republic of Indonesia is prepared through negotiations with the State concerned

10 Kurtubi, “Timor Gap: Udang di Balik Batu?” Fokus Kompas, (2002): 33.

11 Etty R. Agoes (1991), "Rules of Joint Development," (paper presented at the seminar on "Law of the Sea in the 1990's : Offshore Resources Development", a Joint Seminar of the Indonesian Center for the Law of the Sea (ICLOS) and the Netherlands Institute for the Law of the Sea (NILOS), Bandung, 24-26 January 1991.

12 Indonesia. Undang-Undang tentang Landas Kontinen Indonesia (Law regarding Indonesian Continental Shelf), UU No. 1 Tahun 1973, LN No. 2294, Tahun 1973 (Law No. 1 Year 1973, SG No. 2294, Year 1973), art. 3.

13 Before Law No. 1 Year 1973 was issued, the Government of Indonesia issued Promulgation on the Indonesian Continental Shelf in 17 February 1969. 
to determine a boundary line in conformity with legal and equitable principles. Pending the conclusion of such agreements, the Government of the Republic of Indonesia will issue permits for exploration as well as for the production of natural oil and gas and the exploitation of mineral and other natural resources only for the area on the Indonesian side of the median line drawn from the coast of Indonesian outermost islands or, in case the territories of both States adjoin on the same island, on the Indonesian side of a line the points of which are equidistant from the nearest points on the baselines of the territorial sea of the respective State."

When the continental shelves of states are overlapping each other, delimitation of continental shelf of neighbouring states shall be settled through negotiation aimed at achieving common consent. When common consent has not been achieved in relation to continental shelf boundaries, then the median line shall be applied if the coastal territory of Indonesia and coastal territory of neighbouring state are opposite each other. If their coastal territories are adjacent, the equidistance line should be applied.

Since the coast of Australia's Northern Territory and the southern coast of Indonesian territory in East Timor are opposite, their continental shelf overlaps each other. Because the coast of the two states is not up to a distance of 400 nautical miles, ${ }^{14}$ the delimitation has to be effected by bilateral agreement. From 1972 to 1989 , no agreement was achieved in relation to the matter. In the opinion of Indonesia, the delimitation should apply the median line because utilizing the median line would ensure an equitable distribution of continental shelf for each state.

The continental shelf of the Timor Sea in the southern territory of East Timor is the same continental shelf located in the northern territory of Australia which according to Indonesia, means that establishment of jurisdiction limits for each state has to be conducted on the basis of applying median line principle, since this principle can ensure justice in international relations. On the contrary, Australia believes that its continental shelf in parts of the Timor Sea achieves the bathymetric axis line, i.e. the limit named Timor Trench located in the southern coast of East Timor, since Australia considers that the Timor Trench constitutes a natural prolongation of its continent. ${ }^{15}$

Therefore Australia's claim to the continental shelf commences from the north coast of the Northern Territory to the Timor Trench. ${ }^{16}$ Such claim is based on geological and geomorphologic approach, where Australia believes that its continental shelf ends at the Trench of Timor Sea. This belief presumes that the continental shelf existing in Timor Sea between Indonesia and Australia does not constitute the same continental shelf. Australia's perception is absolutely wrong because the continental shelf claimed until maximum limit by the two states is the same continental shelf and not a different one. ${ }^{17}$ This condition was proven by virtue of geological facts from

${ }^{14}$ Kompas, "Tidak Benar, Indonesia Dirugikan di Celah Timor," Kompas (24 February 1989): 1. The Timor Gap, comprises 3 areas or zones, is created by 3 different lines due to different and contradictory approach between Indonesia and Australia. These lines are 1) bathymetric axis line as Australian claim; 2) 200 nautical mile line as Indonesian claim; 3) median line. See also note 8.

${ }^{15}$ Roger S. Clark, "The Timor Gap: The Legality of the Treaty on the Zone of Cooperation in an Area between the Indonesian Province of East Timor and Northern Australia," Pace International Law Review Vol. 4 Issue 1 (1992): 70-72, accessed 19 February 2015, http://digitalcommons.pace.edu/pilr/vol4/iss1/3.

${ }^{16}$ Kompas, loc.cit.

${ }^{17}$ Yoshifumi Tanaka (2), The International Law of the Sea (Cambridge: University Press, 2012), p. 206. While geology relates to the composition and structure of the seabed, geomorphology concerns its shape and form. In general, international courts and tribunals attribute limited importance to geological and geomorphological factors, since currently coastal States may claim the continental shelf as well as an EEZ/FZ of 200 miles, regardless of the geological or geomorphological characteristics of the area, etc. See 
laboratory test which indicates that the end and edge of the continental shelf claimed by Australia does not terminate at Timor Trench, but terminates at the north coast of East Timor. ${ }^{18}$

This condition can be proved based on the geological facts that sediment layer, including sedimentary rock, contained in the seabed and subsoil of the East Timor's northern coast is similar to the sediment layer in the seabed and subsoil of Australia territory's northern coast. ${ }^{19}$ This clearly shows that Australia's perception is wrong and Australia has no reason to claim any jurisdiction over the continental shelf up to the Timor Trench which is so close to Indonesian territory in the southern coast of East Timor. Since the continental shelf of Timor Sea is the same continental shelf, the continental shelf boundary settlement between the two states should be conducted by applying the median line approach because no agreement has been achieved.

Article 6 of Geneva Convention on the Continental Shelf stipulates:

"1. Where the same continental shelf is adjacent to the territories of two or more states whose coasts are opposite each other, the boundary of the continental shelf appertaining to such states shall be determined by agreement between them. In the absence of agreement, and unless another boundary line is justified by special circumstances, the boundary is the median line, every point of the baselines from which the breadth of the territorial sea of each state is measured.

2. Where the same continental shelf is adjacent to the territories of two adjacent states, the boundary of the continental shelf shall be determined by agreement between them. In the absence of agreement, and unless another boundary line is justified by special circumstances, the boundary shall be determined by application of the principle of equidistance from the nearest points of the baselines from which the breadth of the territorial sea of each state is measured."

Application of median line for two states whose coasts are opposite each other, such as Indonesia and Australia, should be carried out not only because this issue is treated in the 1958 Geneva Convention on the Continental Shelf and is still valid, but also because application of median line and equidistance line principles for two states whose coasts are adjacent each other became a practice widely accepted by states and hence, are rules of international customary law which have a binding force on states that are party and non-party to the convention. As a party to 1958 Geneva Convention, Australia should apply the median line principle in delimiting continental shelf boundaries in the Timor Gap as long as no agreement has been achieved

The opinions of both states which is contrary to each other and difficult to resolve had been on for more than ten years, that is, from the beginning of the 1970s to 1989. During that time, the relationship between the two states, mainly the relationship between Indonesian Government and Australian Government, was not very cordial; on one hand, the presence of good neighbourly relationship existed but on the other hand, the relationship of the two states was often rough. This led to conflict which caused an anxiety of severance of diplomatic relation. An instance of unfriendly relation between Indonesia and Australia was when the daily Sydney Morning Herald made a pronouncement on a property owned by the President Soeharto's family (the

note 4 , p. 1 .

18 Kompas, loc.cit.

19 Ibid. 
former president), ${ }^{20}$ causing diplomatic tension between both states.

The Government of Indonesia demanded that the Government of Australia carryout legal actions against Australian press as a manifestation of state responsibility. Although the demand was merely conveyed through its diplomatic representative in Jakarta, the demand was unnecessarily exaggerated by the mass media. Various incidents occurred in East Timor and Jakarta which were related to a community struggle desiring the freedom of East Timor from Indonesian Republic. These incidents always made headlines in Indonesia and had the tendency to be exaggerated; such exaggeration had the potential to disturb the governmental stability and the friendly relations between both states.

The government seriously endeavoured to restore and promote the friendly relation and a variety of efforts by government eventually helped to preserve national stability and the survival of the government in power. The negotiations on Timor Gap which took place for many years were exploited as a means of restoring and promoting the friendly relation and ensuring the stabilization of power and continuation of Soeharto's regime at that time. Therefore, the Government of Indonesia softened its attitude and policy during negotiations on the issue of continental shelf boundaries in the Timor Gap and did not insist on the median line principle as the principle which should be applied in such a situation where a definitive boundary agreement was yet to be achieved.

\section{B. Substance of the Timor Gap Treaty}

Under these circumstances, both states arrived at an agreement for the purposes of committing joint management of natural resources, particularly oil and gas, contained in the continental shelf of Timor Gap. The management cooperation which was also called joint development between Indonesia and Australia was incorporated and declared a treaty named the Timor Gap Treaty. ${ }^{21}$ This treaty was not a treaty of continental shelf boundary in the Timor Sea separating East Timor of Indonesian territory and Australia's Northern Territory. It did not establish the jurisdiction limits of each state on certain areas of the continental shelf that overlapped and piled up on one another; it is a treaty on the joint development of natural oil and gas resources in the Timor Gap, hence, it could be said that the treaty was a provisional arrangement because as long as a definitive treaty on the continental shelf boundaries in Timor Gap was not achieved, the provisional treaty regulating joint development is applied. ${ }^{22}$ The Treaty was established as an interim measure for exploration and exploitation of the resources contained in that area, pending a continental shelf boundary agreement that would bridge the gap existing between the two agreed boundaries of 1971/1972.

The Timor Gap Treaty was established to be valid for a period of 40 years and to commence 30 days after both parties ratified the treaty. This provision was stated in article 32 of 'Treaty on the Zone of Cooperation in an Area between the Indonesian Province of East Timor and Northern Australia' or the Timor Gap Treaty 1989. Except established otherwise, when the treaty terminates, as stated in article 33 of the Timor Gap Treaty, the treaty might be extended for 20 years and the same period of

${ }^{20}$ Akbar Tri Kurniawan, “Soeharto \& Barisan Jenderal Orba, Rezim Militer Indonesia 1976 - 1983,” http://tempo.co/read/news/2010/06/28/109258982/_Jendral-Inti-di-Dapur-Soeharto, accessed 17 February 2015.

${ }^{21}$ Sarong, loc.cit.

22 Kurtubi, loc.cit. 
time would apply each time the treaty was extended, except both parties eventually reached an agreement on delimitation. Furthermore, it was also stated that both parties have a duty to negotiate a settlement on five year boundaries before the treaty or its extension terminates.

The zone of cooperation encompasses an area of $61.000 \mathrm{~km}^{2}$, restricted and limited by a bathymetric axis line in the North, and a 200 nautical miles line measured from Indonesian archipelagic baselines in the South. ${ }^{23}$ In shaping such the zone, the Australian position for a natural prolongation line along the Timor Trough and the Indonesian position for a median line were both accommodated. These limits absolutely reflected the maximum demand of each state. The zone of cooperation embraced 3 areas, i.e. Area C, Area A and Area B from north to south. The northern limit of the zone is drawn along the bathymetric axis of the Timor Trough and its southern boundary is drawn along the 200 nautical miles line from the Island of Timor. The median line is adopted to divide Area A and Area B in the zone. Area A and Area $C$ is divided by a modified line of 1,500 metres isobaths. ${ }^{24}$ Area A was a central area where the regime of real joint development applied. Ministerial Council and Joint Authority were established.

Area A spanned 1,500 metre isobaths in the north and the median line in the South. Area B was limited in the North by the median line and in the south by the 200 nautical miles line measured from the southern coast of East Timor. Area $\mathrm{C}$ was limited by bathymetric axis in the north and in the south by 1,500 metre isobaths. Therefore the relevant part of the zone of cooperation has been divided under Articles 3 and 4 of the Treaty into three Areas.

Area A is in the middle and is to be jointly developed. Area A was jointly exploited by Indonesia and Australia and its proceeds was divided or shared with each party getting 50 percent. Area B, nearest to Australia, is an area of sole Australian jurisdiction. However, Australia will allocate to Indonesia ten percent of the gross Resource Rent Tax revenues, which is equivalent to sixteen percent of the net Resource Rent Tax collected from this Area. Area B was exploited by Australia, but Australia was obliged to give Indonesia 16 percent from net Resource Rent Tax coming from oil production activities in the area. Similarly, Area C, nearest to Indonesia, is an area of sole Indonesian jurisdiction. However, Indonesia will allocate ten percent of contractors' Income Tax revenues from this area to Australia. Area $\mathrm{C}$ was to be exploited by Indonesia; however, Indonesia had an obligation to give 10 percent from the Contractor's Income Tax produced from oil production activities in that area (article 2c). The whole deal $\mathrm{A}, \mathrm{B}$ and $\mathrm{C}$ - obviously comes as a package, and the resources of the total package are thus subject to sharing. ${ }^{25}$

If the substance of the Timor Gap Treaty is investigated thoroughly, particularly the system of production sharing implemented in the three areas above, it becomes very clear that Indonesia was absolutely short-changed by the treaty. Although the percentage which was Indonesia's portion is more than Australia's portion, it was not in Indonesia's interest. Among the three areas which became zones of cooperation, the richest zone based on oil and gas reserve is zone $\mathrm{B}$, which was exploited by Australia. ${ }^{26}$

${ }^{23}$ Ans, “Celah Timor Terancam Lepas," Teropong Kompas (2001): 26. See also Sun Pyo Kim, Maritime Delimitation and Interim Arrangements in North East Asia (The Hague: Martinus Nijhoff Publishers, 2004), p.103.
${ }^{24}$ Ibid.
${ }^{25}$ Clark, loc.cit.
${ }^{26}$ Ans, loc.cit. 
The case of zone $\mathrm{C}$ under the jurisdiction of Indonesia is absolutely disappointing. Although Indonesia was entitled to 90 percent from Contactors Income Tax and Australia only 10 percent, the zone had no oil and gas content at all because waters existing above the zone have a depth of 1,500 metre from the water surface which makes it impossible to conduct any exploration and exploitation in the zone. The implication of this is that, though Indonesia had 90 percent of the proceeds of zone $c$ on paper, in reality, it had nothing because 90 percent of nothing is nothing. ${ }^{27}$

After the twenty-seventh province of Indonesia Republic became an independent and sovereign state based on the referendum result desiring East Timor's separation from the Union State of Indonesian Republic, the Timor Gap Treaty signed on 11 December 1989 by Secretary of State of Indonesia, Ali Alatas, and his counterpart from Australia, Senator Garreth Evans, automatically ended.

\section{Termination of the Timor Gap Treaty}

Timor Gap Treaty or Treaty on the Zone of Cooperation in an Area between the Indonesian Province of East Timor and Northern Australia, was signed on board an aircraft of the Australian Air Force flying above the disputed zone. The treaty ceased to be valid after the Foreign Minister of Indonesia, Alwi Syihab, sent a letter to the Foreign Minister of Australia, Alexander Downer, on May $252000 .{ }^{28}$ In the letter, the minister referred to the 1989 Timor Gap Treaty achieved through Technical Level Meeting between the two governments and Australia's Government responsibility to respect the Timor Gap Treaty concluded in Jakarta from 1-3 of February 2000. He declared that the Timor Gap Treaty of 1989 ceased to in effect when the authorities of Indonesia shifted the issue of East Timor to the United Nations. He also stated that any operational consequences which arises due to termination of the treaty would be settled and implemented in accordance with practical provisions jointly agreed. The expectation was that the letter would be understood by the Government of Australia and a reply of the Foreign Minister of Australia would constitute mutual understanding between Indonesia and Australian regarding the status of the treaty and its operational consequences. That was the statement of the Foreign Minister of Indonesia, Alwi Shihab, regarding the status of the Timor Gap Treaty as it could be read through his letter or mail sent to foreign Minister Alexander Downer on 25 May 2000.

In June 2000, the Foreign Minister of Australia replied the mail. ${ }^{29}$ Essentially, the Foreign Minister of Australia acknowledged the statement of the Foreign Minister of Indonesia (Alwi Shihab) as stipulated in his mail which, inter alia, declared that he acted on behalf of Indonesian Government. It could be understood by the Government of Australia that the mail of Foreign Minister of Indonesia and Foreign Minister of Australia would constitute mutual understanding between the two governments regarding the status of Timor Gap Treaty and the operational consequences in any field. Therefore, through the mail correspondence between both Foreign Ministers, the Timor Gap Treaty concerning joint management of natural resources ceased to be in effect. Nevertheless, various issues could emerge operationally in the field and these still required settlement which have to be done by the two states or even by the three states. A crucial issue which needs and requires settlement is the issue of

\footnotetext{
27 Ibid.

28 Kusumaatmadja, op.cit. pp. 1-2

29 Ibid.
} 
maritime boundaries, particularly delimitation of the exclusive economic zone in Timor Sea between Indonesia and Timor Leste.

On 5 July 2001, a Memorandum of Understanding on Timor Sea Arrangement was signed by the Foreign Minister of Australia (Alexander Downer), Minister Official for Political Affairs of UNTAET (Peter Galbraith) and Minister for Economy Affairs (Mari Alkatiri). This agreement established a production sharing formula for oil and gas existing in Timor Sea, where the production sharing was committed on the basis 90 percent for Timor Leste and 10 percent for Australia. ${ }^{30}$

The signing of the agreement resulted in a protest by a member of the provisional parliament of Timor Leste, Angela de Freitas, who was so angry and shouted, 'don't sell our country to foreign country'. ${ }^{31}$ Although this lady was thrown out of the ceremony room by security guards, various groups both in Timor Leste and overseas, including in Indonesia expressed sympathy toward her attitude in anticipating a potential damage due to the Timor Sea oil production sharing contract that was signed and ratified by the Government of Timor Leste. Indonesia expressed sympathy as well to Angela de Freitas.

Although Timor Leste gained 90 percent and Australia only 10 percent, Australia has the ability to profit and benefit as much as possible because it is responsible for providing capital and technology to carry out activities of exploration, exploitation, production, transportation, marketing of oil and gas and all the industrial products based on oil and gas. Australia was smart to invest in capital and technology, constructing all facilities and infrastructures needed for industrial activities from upstream to downstream. Australia has the ability to accurately monitor activities in the continental shelf of Timor Sea relating to production, transportation and marketing of the products. It can also calculate operational expenses and the price of oil in the international market. This results in maximum profit and benefit for Australia even though Timor Leste has the right to obtain 90 percent from the profit.

\section{Maritime Delimitation Based on the Equitable Solution Principle}

In 1999, a geopolitically significant change emerged in Timor Sea as a consequence of Timor Leste's birth as a sovereign state with the result that the Timor Sea was no longer owned by two states any more but by three states; Indonesia, Australia and Timor Leste. Therefore, all the maritime boundaries (in Timor Sea) concluded between Indonesia and Australia and between Australia and Timor Leste without involving the third country are illegal and must be trilaterally renegotiated by the three states that border the Timor Sea. ${ }^{32}$

\section{A. Unilateral Maritime Expansion of Timor Leste State}

In 2002, the parliament of Timor Leste adopted territory limit law and at the

${ }^{30}$ Rawul Yulian Rahman, “Upaya Timor Leste Dalam Penyelesaian Garis Tapal Batas Dengan Australia," eJournal Ilmu Hubungan Internasional Vol. 1 No. 2 (2013): 275, accessed 10 January 2015, http:// ejournal.hi.fisip-unmul.ac.id/site/wp-content/uploads/2013/06/jurnal\%20ok\%20(06-04-13-05-39-36). pdf.

31 Kompas, loc.cit.

32 Bambang Susanto, "Kajian Yuridis Permasalahan Batas Maritim Wilayah Laut Republik Indonesia (Suatu Pandangan TNI AL Bagi Pengamanan Batas Wilayah Laut RI)," Indonesian Journal of International Law Special Edition (December 2004): 46, 55. 
same time, unilaterally established maritime expansion. ${ }^{33}$ The unilateral declaration was done by claiming 100 nautical miles from the former lines of Timor Gap. Timor Leste broadened and expanded its maritime zone towards the western and eastern zone from the former lines of joint development in the Timor Gap with the result that its expansion seized oil and gas wells: Laminaria/Carolina in the western zone and Greater Sunrise in the eastern zone of Timor Gap. The new maritime zones due to the expansion was declared as the exclusive economic zone of Timor Leste so that the expansion conducted by the small country negatively affected the Union State of Indonesian Republic. ${ }^{34}$

Indonesia has a government regulation called government regulation number 37, year 2008 regarding geographical coordinate list for base points of Indonesian archipelagic baselines. The government regulation established about 160 outermost islands and natural features as base points in establishing archipelagic baselines within its national waters. Based on this government regulation, the maritime expansion of Timor Leste absolutely threatens and endangers the sovereignty and territorial integrity of Indonesia.

This government regulation is implanted in Indonesian law number 6, year 1996 regarding national waters and the law number 43, year 2008 regarding state territory. These laws are also implanted in the United Nations Convention on the Law of the Sea, 1982 (UNCLOS), which had been ratified by the Republic of Indonesia through the law number 17 , year 1985 . As a party to the convention, Indonesia has the obligation to make maritime delimitation, mainly delimitation of exclusive economic zone with Timor Leste through negotiation even though Timor Leste is not a party to the convention, since this zone overlaps the two states. Indonesia and Timor Leste are two simultaneously adjacent and opposite states. The adjacent area is the Eastern Timor Leste (main) and the land territory of Indonesia in Eastern Nusa Tenggara (Nusa Tenggara Timur), while the opposite area is the Eastern Timor Leste and the Wetar Island of Indonesia.

\section{B. Implementation of The Equitable Solution Principle in Maritime Delimitation}

The delimitation of the exclusive economic zone/continental shelf between States with opposite or adjacent coasts shall be effected by an agreement on the basis of international law, as referred to in Article 38 of the Statute of the International Court of Justice, in order to achieve an equitable solution (article 74/83, paragraph 1). ${ }^{35}$ The equitable soluion is aprinciple to arrange the maritime delimitation in the exclusive economic zone/continental shelf. The emergence of this principle during the third conference on the law of the sea was brought about by disagreements and debates between the group of states supporting 'the Equidistance-Special Circumstances rule $^{36}$ and the group of states supporting the 'Equitable principles'. Due to the

33 Jems de Fortuna, “Pemerintah Diminta Tanggapi Serius Perluasan Laut Timor Leste," http:// www.tempo.co/read/news/2006/01/31/05873209, accessed 20 February 2015.

34 Rifky Pradana, "Timor Leste Bikin Ulah: Caplok Wilayah R.I.," https://www.mail-archive.com/ ekonomi-nasional@yahoogroups.com/msg04699.html, accessed 20 February 2015.

35 R.R. Churchill and A.V. Lowe, The Law of the Sea (Manchester: Manchester University Press, 1983), pp.126-128.

${ }_{36}$ This rule was first articulated in the 1958 Geneva Convention on the Continental Shelf. Article 6(2) of the Convention declared that:

"Where the same continental shelf is adjacent to the territories of two adjacent States, the boundary of the continental shelf shall be determined by agreement between them. In the absence 
fact that no consensus was reached between the two groups, the President of the conference had no choice but to propose a new formula which did not refer to the two terms, 'equidistance' and 'equitable principles' with regard to the delimitation of the continental shelf and the exclusive economic zone. ${ }^{37}$ The formula only established the 'final aim' of maritime delimitation, which it termed the achievement of an 'equitable solution (equitable result)'. Some states do not accept 'the equidistance-special circumstances' rule because the equidistance method might produce an inequitable result in certain cases. In contrast, other states argue that this rule can guarantee 'predictability' concerning maritime delimitation. ${ }^{38}$

In the 1993 Jan Mayen case, ${ }^{39}$ the ICJ considered the meaning of equitable principles. In the view of the court with regard to the delimitation of the continental shelf between opposite states, the equidistance-special circumstances rule formulated in article 6 of the 1958 Convention on the Continental Shelf is not materially different from the equitable principles-relevant circumstances rule which existed in customary international law. Furthermore the ICJ assimilated the two rules regarding the delimitation of the exclusive economic zone, stating that the statement of an 'equitable solution' as the aim of any delimitation process reflects the requirements of customary law as regards the delimitation of continental shelf and of exclusive economic zone. Thus, whereas the earlier cases had rejected the obligatory character of the equidistance method and tried to clarify the meaning of equitable principles, the 1993 Jan Mayen case intended to deny the substantial difference between the two rules and to justify the provisional use of the equidistance method. ${ }^{40}$ In the 2001 Maritime Delimitation and Territorial Questions of the Qatar v. Bahrain case, ${ }^{41}$ the equidistance-special circumstances rule which is applicable in particular to the delimitation of the territorial sea, and the equitable principles-relevant circumstances rule as developed since 1958 in case-law and State practice with regard to the

of agreement, and unless another boundary line is justified by special circumstances, the boundary shall be determined by application of the principle of equidistance from the nearest points of the baselines from which the breadth of the territorial sea of each state is measured."

It should be noted that in the absence of an agreement between the States involved, the equidistance method cannot be applied without regard to special circumstances. That is why this rule has been called 'the Equidistance-Special Circumstances rule'. In spite of the codification of the Equidistance - Special circumstances rule, the ICJ refused to regard this rule as a rule of customary international law in the 1969 North Sea Continental Shelf cases. See also Ki Beom Lee, "The Flexibility of the Rules Applied in Maritime Boundary Delimitation," (presented at Third Year PhD Presentation Series, School of Law, the University of Edinburgh, 2011).

37 Tore Henriksen and Geir Ulfstein, "Maritime Delimitation in the Arctic: The Barents Sea Treaty," Ocean Development \&International Law Vol. 42 No. 1, (February 2011): 4-5.

${ }^{38}$ Churchill and Lowe, op.cit., pp. $10-11$.

${ }^{39}$ In 1989 there was no maritime boundary in place either between Iceland and Greenland (Denmark) or between Greenland and Jan Mayen (Norway), while there was a boundary between Iceland and Jan Mayen. Under these circumstances Denmark (Greenland), Iceland and Norway (Jan Mayen) concluded a fisheries agreement on capelin fishing in the waters between Greenland, Iceland and the Norwegian island of Jan Mayen. The area of this agreement only has a conceptual scope, which is not specifically defined. According to the Agreement, all parties shall try to reach an agreement on the Total Allowable Catch (TAC) of capelin each year. If an agreement is not achieved, Iceland has the responsibility of deciding the TAC. Once the TAC is decided upon, Iceland receives 78 percent of it and Denmark and Norway both get 11 percent. Vessels flying the flag of one Party are allowed to fish capelin in the waters even within 200 miles from the other Parties' coasts under the limits of their flag- States' fishing quota. (Kim, op.cit., p.123).

${ }^{40}$ Ibid.

41 Barbara Kwiatkowska, "The Qatar v. Bahrain Maritime Delimitation and Territorial Questions Case," IBRU Maritime Briefing Vol. 3 No. 6 (2003): 232-233. 
delimitation of the continental shelf and the exclusive economic zone are closely interrelated. In the 2002 Land and Maritime Boundary (Cameroon v. Nigeria) case, the ICJ applied equitable principles-relevant circumstances method, which is very similar to the equidistance-special circumstances method applicable in delimitation of the territorial sea. ${ }^{42}$ It involves first drawing an equidistance line, then considering whether there are factors calling for the adjustment or shifting of that line in order to achieve an 'equitable result'. The result of the application of equitable principles must be equitable. It is however the result which is predominant; the principles are subordinate to the goal. The equitableness of a principle must be assessed in the light of its usefulness for the purpose of arriving at an equitable result. ${ }^{43}$

Unclear maritime boundaries may cause a variety of problems as seen in incidents which occurred in the relationship between Indonesia and Malaysia some years ago. The maritime boundary delimitation between Indonesia and Timor Leste needs to be accelerated without necessarily expecting any land boundary completeness. Negotiation should commence to determine, besides dispute settlement mechanism, fundamental things such as appropriate juridical foundation, available method (median line, equidistance line) aimed at achieving equitable solution or equitable result relating to maritime delimitation between Indonesia and Timor Leste.

So far Australia considered that Timor Island and Australian territory had respective different continental shelf with the result that Australia had unilaterally claimed that the Timor Trough constituted and integral part of the Australian continental shelf with the result that $85 \%$ of the Timor Sea was under its authority and control. ${ }^{44}$ Whereas in fact Australia and Timor Island was located in only one continental shelf, so that the delimitation of certain seabed areas between Indonesia and Australia should apply median line principle aimed at achieving equitable result.

Maritime delimitation between Indonesia and Timor Leste should apply equitable solution principle, while taking into account relevant circumstances, particularly geographical factors existing in both states. This principle was used in recent years in Barbados and Trinidad and Tobago, 2006, in Romano and Ukraine ${ }^{45}$ case and in other cases of maritime delimitation. ${ }^{46}$ What kind of maritime delimitation method

42 International Court of Justice (1), Land and Maritime Boundary between Cameroon and Nigeria (Cameroon v. Nigeria: Equitorial Guinea intervening), Judgement, I.C.J. Reports 2002, p. 303. See also Churchill and Lowe, op.cit., pp. 8 - 9.

43 Oegroseno, op.cit.: 193 - 195.

${ }^{44}$ Yayasan Peduli Timor Barat, "YPTB Kembali Desakkan Perundingan Ulang Soal Laut Timor," http://www.merdeka.com/politik/yptb-kembali-desakkan-perundingan-ulang-soal-laut-timor-2rydzqp. html, accessed 20 February 2015.

45 In many cases small islands were only given partial effect or even no effect to maritime delimitation. Serpents Island of Ukraine as geographical factor (relevant circumstances) had a right to claim territorial sea, but in 2009 ICJ stated that Serpents Island could not be used as basepoint to construct equidistance line as boundary line of the exclusive economic zone or continental shelf between Ukraina and Romania, since if such the island was used as basepoint to construct delimitation of exclusive economic zone or continental shelf, it would be contrary to the proportionality or equity. Regarding the Timor Gap which Australia and Timor Leste possibly considered as geological and geomorphological factor (relevant circumstances), in general, international courts and tribunals attribute limited importance to geological and geomorphological factors. A reason is that currently coastal States may claim the continental shelf as well as an exclusive economic zone or fishery zone of 200 miles, regardless of the geological or geomorphological characteristics of the area so that they become irrelevant in the process of delimitation. Moreover, in the majority of agreements the characteristics of the seabed did not have a significant effect on the location of maritime boundaries. (Tanaka (2), op.cit., pp. 204 - 206).

${ }^{46}$ Clark, op.cit., pp. $4-5$. 
should be used in achieving equitable solution or equitable result? The maritime delimitation, mainly in the Timor Sea should be undertaken in two phases or steps: first, a provisional equidistance line should be drawn based on the relevant coast lines of both states and second, relevant circumstances that call for adjustment should be identified. The function of relevant circumstances existing in both countries to verify that the provisional equidistance line is not, in light of the particular circumstances of the case, perceived as inequitable so that verification could strengthen the status of equidistance ${ }^{47}$ The relevant circumstances have increasingly been attached to geographical consideration since in determination of a single delimitation line for the continental shelf and the exclusive economic zone, geographical circumstances were perceived as neutral compared to geological and resource-related circumstances. International courts and tribunals have certain discretion to define and weigh these circumstances within the overall requirement of achieving an equitable solution in a particular case. A third phase or step employed in the Romano and Ukraine case should be applicable in maritime delimitation between Indonesia and Timor Leste. In the Romano v. Ukraine case, the court was required to evaluate whether the line emerging from steps one and two leads to an 'inequitable result' by a marked disproportion between the ratio of respective coastal lengths and the ratio of relevant maritime area of each state. This step which resurrects the proportionality calculation seems to strengthen the emphasis on geographical criteria in maritime delimitation. ${ }^{48}$

Termination of the Timor Gap Treaty between Indonesia and Australia in 1999 does automatically eradicate the object named the Timor Gap. There is no reason for Timor Leste government to carry out maritime expansion by applying former Timor Gap lines as baselines to construct the exclusive economic zone to a distance of 100 nautical miles. This unilateral expansion act not only seizes a certain area of Indonesian archipelagic waters and territorial seas in the Timor Sea, but also denies and neglects maritime delimitation principle based on equitable solution.

In ICJ decision on Sipadan/Ligitan case, a separate opinion of Judge Oda declares that although the two islands (Sipadan and Ligitan) are owned by Malaysia or in other words both islands are under its sovereignty, it doesn't influence maritime delimitation, particularly delimitation of continental shelf or exclusive economic zone in Celebes Sea between Indonesia and Malaysia. Although both islands are qualified as special circumstances, their existence doesn't mean that they can be used as base points in establishing baselines and constructing maritime delimitation in disputed areas of Celebes sea, since the maritime delimitation can be conducted by disregarding the existence of both islands. ${ }^{49}$

47 Ibid.

48 Tanaka (2), op.cit., pp.193 - 195.

49 International Court of Justice (2), Sovereignty over Pulau Ligitan and Pulau Sipadan (Indonesia) Malaysia,) Judgment, I.C.J. Reports 2002, p. 625. See also Marcel Hendrapati, "Implication of the ICJ Decision Respecting to Sipadan-Ligitan Case towards Basepoints and Maritime Delimitation," International Journal of Sciences: Basic and Applied Research Vol. 14 No. 1 (January 2014): 382-384. Nugzar Dundua, on his view "Delimitation of Maritime Boundaries between Adjacent States," states that

The ICJ and arbitral tribunals tried several times to determine the concept of equity: Equity as a legal concept is a direct emanation of the idea of Justice. The Court is bound to apply equitable equity as a part of general international law. When applying positive international law, a court may choose among several possible interpretations of the law the one which appears, in the light of the circumstances of the case, to be closest to the requirements of justice. The Court further stated that "[I]t is not a question of applying equity simply as a meter of abstract justice, but of applying a rule of law" during the 1969 North Sea case, and later, during the 1985 Libya/Malta case, it reiterated that "[t]he Justice of which equity is an emanation, is not abstract justice but justice according to 
In essence, the concept of Judge Oda declared in his separate opinion contains a kind of justice as immaterial values ${ }^{50}$ with the result that his concept could become a noble reference which could be expected to apply during negotiations conducted by Indonesian and Timor Leste. Although Timor Leste owns and uses the former lines of Timor Gap as guidelines and baselines to establish its maritime limits to a distance of 100 nautical miles, these lines do not influence any maritime delimitation of exclusive economic zone of Indonesia. If Timor Leste considers the existence of the former Timor Gap lines as special or relevant circumstance, their existence does not necessarily have a direct bearing on the delimitation of exclusive economic zone between Timor Leste and Indonesia. This situation can be understood because according to special circumstances rule, a delimitation line could also be drawn disregarding the existence of the former Timor Gap lines. The application of the former lines will be contrary to proportionality principle, since it would cause in equilibrium between the length of the baselines existing in Timor Leste's coast and maritime areas claimed by the small country. Disregarding or setting aside its existence as baselines should be conducted during negotiations of maritime delimitation of overlapping parts exclusive economic zone within the Timor Sea. In this regard, the authorities of Indonesian should use the Romania v. Ukraine case, where the Serpents Island was not used as base point, to draw maritime delimitation line in the Black Sea. By virtue of many agreements of maritime delimitation neglecting and setting aside the small islands as base points, they had no effect in constructing maritime delimitation line. This condition could be used as a reference by the authorities when they carryout negotiating measures to achieve an agreement on maritime boundaries in the Timor Sea.

\section{Conclusion}

Treaty on the Zone of Cooperation in an Area between the Indonesian Province of East Timor and Northern Australia or Timor Gap Treaty isn't a treaty on continental shelf boundary between Indonesia and Australia, but a joint development treaty applied in Timor Sea which embraces three joint zones (zone A, B and C). The production sharing is not just because it is not beneficial to Indonesia while Australia benefits greatly. The joint development arrangement which doesn't reflect the principle of justice in bilateral relationship certainly is not separated from the genesis of the process of such treaty loaded with political interest for Soeharto regime and accommodating Australian interest, since on one hand, long before signing the treaty, Australia had conducted exploration and exploitation in certain parts of Timor Sea that is very near to East Timor coasts. On the other hand, the treaty concluded by the Indonesian government is an attempt by the regime to hold on to power. Nevertheless, the treaty had already been terminated by mutual governmental correspondences on the occurrence of power transfer from Indonesian Republic to UNTAET and on the need for negotiating maritime delimitation in order to avoid any potential conflict relating to it.

Maritime delimitation conflict emerged after Timor Leste made unilateral act aimed

\footnotetext{
the rule of law."

50 The material value would decrease and would even be exhausted when they are distributed by the owner, whereas immaterial values such as goodness, truth, honesty, fairness, justice, etc., would be increasingly fertile and strong when they are distributed by the owner. (Suri RatnapalaJurisprudence (Cambridge: Cambridge University Press, 2009), pp. 333-334).
} 
at claiming exclusive economic zone to a distance of 100 nautical miles measured from the former lines of Timor Gap because its act seized certain parts of Indonesian national waters, including oil fields called Coralina Laminaria and Greater Sunrise. This fact motivated Indonesia and Timor Leste to agree on commencing negotiations focused on maritime delimitation based on the rules of international law to achieve equitable result. Negotiations of the two adjacent and opposite states must consider not only production sharing agreement in the former Timor Gap between Timor Leste and Australia, but also other relevant circumstances, especially the proportionality as a geographical factor, since without taking into account the geographical factors, it is difficult and even impossible to achieve equitable result regarding the delimitation of exclusive economic zone.

In the framework of achieving such equitable result, it is my recommendation that the Indonesian delegation should try to set aside the former lines of Timor Gap in any negotiation with Timor Leste's delegation because the application of the former lines as special or relevant circumstances would disturb and violate the principle of proportionality which represents and reflects justice principle

\section{Bibliography}

\section{Legal Documents}

Convention on the Law of the Sea. Montego Bay, 10 December 1982. United Nations Treaty Series. Vol. 1833. No. 31363.

Indonesia. Peraturan Pemerintah tentang Daftar Koordinat Geografis Titik-Titik Garis Pangkal Kepulauan Indonesia (Government Regulation regarding List of Geographic Coordinates of Baselines of Indonesian Archipelago), PP No. 38 Tahun 2002, LN No. 72 Tahun 2002 (Government Regulation Number 38 Year 2002, SG No. 72 Year 2002).

Indonesia. Peraturan Pemerintah mengenai Perubahan Peraturan Pemerintah tentang Daftar Koordinat Geografis Titik-Titik Garis Pangkal Kepulauan Indonesia (Government Regulation regarding Changes of Government Regulation regarding List of Geographic Coordinates of Baselines of Indonesian Archipelago), PP No. 37 Tahun 2008, LN No. 77 Tahun 2008 (Government Regulation Number 37 Year 2008, SG No. 77 Year 2008).

Indonesia. Undang-Undang tentang Perairan Indonesia (Law regarding Indonesian Water), UU No. 6 Tahun 1996, LN No. 73 Tahun 1996 (Law No. 6 Year 1996, SG No. 73 Year 1996).

International Court of Justice. Land and Maritime Boundary between Cameroon and Nigeria (Cameroon v. Nigeria: Equitorial Guinea intervening). Judgement. I.C.J. Reports 2002. P. 303.

International Court of Justice. Sovereignty over Pulau Ligitan and Pulau Sipadan (Indonesia/ Malaysia). Judgment. I.C.J. Reports 2002. P. 625.

\section{Books}

Churchill, R.R. and A.V. Lowe. The Law of the Sea. Manchester: Manchester University Press, 1983.

Djalal, Hasjim. Mengelola Potensi Laut Indonesia. "Mengelola Potensi Laut Indonesia." Presented at Pelatihan Diplomasi dan Hubungan Internasional Bagi Pejabat Pemerintah Daerah Sulawesi Selatan, Makassar, December 2003. 
Djalal, Hasjim. Perjuangan Indonesia di Bidang Hukum Laut. Jakarta: Badan Penelitian dan Pengembangan, Departemen Luar Negeri Republik Indonesia, 1986.

Dundua, Nugzar. Delimitation of Maritime Boundaries between Adjacent States.United Nations - The Nippon Foundation Fellow: 2006.

Etty R. Agoes (1991). "Rules of Joint Development." Paper presented at the seminar on "Law of the Sea in the 1990's : Offshore Resources Development", a Joint Seminar of the Indonesian Center for the Law of the Sea (ICLOS) and the Netherlands Institute for the Law of the Sea (NILOS). Bandung, 24-26 January 1991.

Kim, Sun Pyo. Maritime Delimitation and Interim Arrangements in North East Asia. The Hague: Martinus Nijhoff Publishers, 2004.

Kusumaatmadja, Mochtar. Hukum Laut International Law. Bandung: Penerbit Binacipta, 1978.

Lee, Ki Beom. "The Flexibility of the Rules Applied in Maritime Boundary Delimitation." Presented at Third Year PhD Presentation Series, School of Law, the University of Edinburgh, 2011.

Prescott, Victor and Clive Schofield. The Maritime Political Boundaries of the World. Leiden: Martinus Nijhoff Publishers, 2005.

Ratnapala, Suri . Jurisprudence. Cambridge: Cambridge University Press, 2009.

Tanaka, Yoshifumi. Predictability and Flexibility in the Law of Maritime Delimitation. Oxford: Hart Publishing, 2006.

Tanaka, Yoshifumi. The International Law of the Sea. Cambridge: University Press, 2012.

\section{Articles}

Ans. "Celah Timor Terancam Lepas.” Teropong Kompas (2001): 26.

Clark,Roger S. "The Timor Gap: The Legality of the Treaty on the Zone of Cooperation in an Area between the Indonesian Province of East Timor and Northern Australia." Pace International Law Review Vol. 4 Issue 1 (1992). Accessed 19 February 2015. http://digitalcommons.pace.edu/pilr/vol4/iss1/3.

Evans, Malcolm D. "Relevant Circumstances and Maritime Delimitation." The International and Comparative Law Quarterly Vol. 40 No. 1 (January 1991): 1-33.

Henriksen, Tore and Ulfstein Geir, "Maritime Delimitation in the Arctic: The Barents Sea Treaty." Ocean Development \&International Law Vol. 42 No. 1 (February 2011):1-21.

Hendrapati, Marcel. "Malaysia Tidak Berhak Menumpang Pada Azas Negara Kepulauan." Jurnal Hukum Internasional Jurisdictionary Vol. 1 No. 2 (April 2005).

Hendrapati, Marcel. "Implication of the ICJ Decision Respecting to Sipadan-Ligitan Case towards Basepoints and Maritime Delimitation." International Journal of Sciences: Basic and Applied Research Vol. 14 No. 1 (January 2014): 374-393.

Kompas. “Pembagian Tambang Minyak di Celah Timor Merugikan.” Kompas (1989): 1.

Kurtubi. "Timor Gap: Udang di Balik Batu?" Fokus Kompas, (2002): 33.

Kwiatkowska, Barbara. "The Qatar v. Bahrain Maritime Delimitation and Territorial Questions Case." IBRU Maritime Briefing Vol. 3 No. 6 (2003).

Oegroseno, Arif Havas. "Status Hukum Pulau-Pulau Terluar Indonesia." Indonesian Journal of International Law Vol. 6 No. 3 (April 2009).

Rahman, Rawul Yulian. "Upaya Timor Leste Dalam Penyelesaian Garis Tapal Batas Dengan Australia." eJournal Ilmu Hubungan Internasional Vol. 1 No. 2 (2013): 275-284. Accessed 10 January 2015. http://ejournal.hi.fisip-unmul.ac.id/ 
site/wp-content/uploads/2013/06/jurnal\%20ok\%20(06-04-13-05-3936).pdf.

Sarong, Frans. “Celah Timor, Daerah Tumpang Tindih.” Teropong Kompas (2001): 25.

\section{Websites}

de Fortuna, Jems. "Pemerintah Diminta Tanggapi Serius Perluasan Laut Timor Leste." http://www.tempo.co/read/news/2006/01/31/0587320. Accessed 20 February 2015.

Kurniawan, Akbar Tri. "Soeharto \& Barisan Jenderal Orba, Rezim Militer Indonesia 1976 - 1983." |http://tempo.co/read/news/2010/06/28/109258982/ Jendral-Inti-di-Dapur-Soeharto. Accessed 17 February 2015.

Pradana, Rifky. "Timor Leste Bikin Ulah: Caplok Wilayah R.I..” https://www.mailarchive.com/ekonomi-nasional@yahoogroups.com/msg0 4699.html. Accessed 20 February 2015.

Yayasan Peduli Timor Barat. "YPTB Kembali Desakkan Perundingan Ulang Soal Laut Timor." http://www.merdeka.com/politik/yptb-kembali-desakkanperundingan-ulang-soal-laut-timor-2rydzqp.html. Accessed 20 February 2015. 